ンサートが開かれ，水曜日夜にはバンケットが夜 12 時過 ぎまで行われた，夕食中は楽器演奏, 歌, パフォーマンス と行われ，非常に楽しい一時を過ごした.

余談であるが，今回実行委員の一人である友人の Antonio Cunha 教授の案内で彼の大学と学科施設, 研究室を見 学させていただいた。研究施設を見学して感じたことは, 必ずしも新しい装置があるわけではないが，ほほ全ての成 形加工機（射出，押出，インフレーション, Tダイとフィ ルム引取機，ブロー，真空，プレス， SCORIM 装置など) を揃え，解析装置（徵分析，レオロジー，光学顕微鏡，機 械試験など）も充実しており，さらに十分な研究スペース を保有している．日本の成形加工に関する大学の研究設備
と比較すると，研究環境が非常に充実している．また前述， Ogale 教授と話をしたところ, 彼は Center for Advanced Engineering Fibers and Films (CAEFF : MIT と Clemson 大）のメンバーで, CAEFF は米国科学財団がサポートす る工学研究センターであり, 今後 10 年間継続的に, 「Films \& Fibers」の研究に対して国が助成を行うそうである. このような諸外国の研究体制を目のあたりにし, 日本の成 形加工に関する早急なる研究体制の充実と産学官の連携実 現を切実に感じる.

来年の PPS-19 は, 2003 年 7 月 7 日〜10 日にオーストラ リア・メルボルンで開かれる. 日本から多くの研究者が参 加されることを希望し，報告を終わらせていただく．

\title{
Polymer Processing Society 18th Annual Meeting 参加報告
}

PPS は成形加工に関する国際会議としてはアメリカで 開催されるANTECに次ぐ規模であり，ヨーロッパ，北 米, アジアの 3 力所を持ち回りで毎年開催される. 第 18 回目である今回はポルトガル第二の都市 Porto の北東に位 置する小都市 Guimarães で行われた. Porto からの交通手 段も少なく不便きわまりない町ではあるが，ここには本会 議の議長である Covas 教授の在職する Minho 大学があり （図 1)，本会議もその大学の施設を利用し開催された．本 学会の内容については同誌に他者からまとまった報告があ ることから，発表件数やその内訳などの概要は省略し，ま た他報告者とはなるべく異なった視点で記したいと思う。

さて本会議の特徴の 1 つは押出成形に関する講演件数の

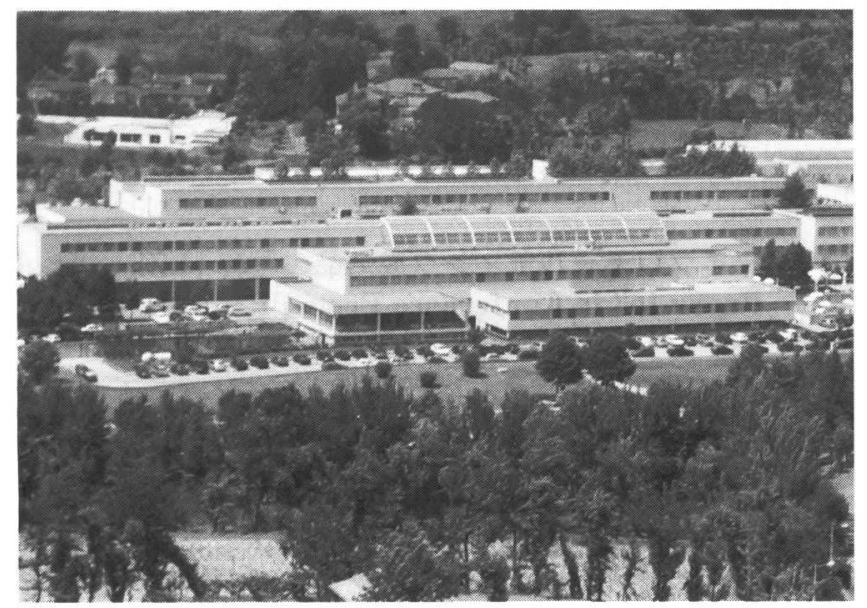

图 1 PPS 18 が開催された Minho 大学（Guimarãesの城 より撮影)

\footnotetext{
* Ishikawa, Takeshi

三菱化学侏 科学技術研究センターポリマー加工研究所

四日市市東邦町 1 ( $(\bar{T} 510-8530)$

2002.7.2 受理
}

多さではないだろうか. 全講演件数 470 件のうち, Mixing, Compounding \& Blending. Extrusion \& Extrusion Processes, Reactive Processingの各セッションを合計すると 161 件と, 3 件に 1 件が押出成形に関する講演ということ になる（伊藤先生による学会報告, 表 2 参照)。これは射 出成形が中心の本学会年会との大きな相違である、筆者は この押出成形に関する講演を中心に聴講したが, 目新しい 材料や加工技術は見られないものの，従来の加工技術の範 囲内で計測や観察を駆使することにより，加工プロセス中 で生じる現象やその進展を解析する技術が着実に進歩して いる，との印象を受けた. PPS という学会にはややアカ デミックさが要求されるのであろうか, 製品の市場価值が 高い低いにかかわらず，最新の解析技術を応用した現象の 解明やモデリング，シミュレーションによる予測に重点が 置かれているようである. 以下に筆者が興味を持った講演 を幾つか紹介したい。

Vergnes" ${ }^{1}$ は軸押出機の滞留時間分布（RTD）をUV 蛍光法により実施している. 彼の方法の特徽は, 押出機の 軸方向の多くの简所での同時オンライン測定を可能にした ところであり，このことによりスクリュエレメントごとの RTD を予測することに成功している. 二軸押出機のスク リュ設計には，ミキシング部そのものの性能を十分把握す ることが必要であるが，本研究結果はある種の混合性に関 してそれを可能にするものである。もちろんこの研究の目 的はこの結果を物理モデルで表現し, 彼の開発する二軸解 析ソフト Ludovicにフィードバックすることである.

Bastian² らは彼が Potente 教授の下で行ったポリマーブ レンドの可塑化挙動の解析を, 新天地である German Institute for Polymersでも引き続き実施している. 透明のコー ンアンドプレートにモデルサンプルを仕込み，せん断速度 の有無の下で可塑化挙動を可視化した結果, せん断速度の 存在により著しく可塑化が早く進行することが確認された。 
装置上の問題で実際の押出機に対応するような高せん断領 域の観察は不可であるが，可塑化挙動を解明する上で興味 深い研究と思われる。

Huneault ${ }^{31}$ らは可視化クエット流動装置を利用して各種 ポリマーブレンドの分散を可視化し，そのビデオ撮影結果 を用いてメカニズムを説明した。中でも興昩深いのは粘弾 性の Boger 流体を液滴に、ニュートン流体である PDMS をマトリクスに用いた結果である．液滴はBoger 流体の 持つ第一法線応力差から流動方向に対して垂直方向に延ば され，尾の先端から徐々に分裂が始まるというものである (図2)。これは界面張力起因の不安定性とは全く異なり, 液滴とマトリクスの速度差から生じる流動に起因する不安 定性と考えられる。

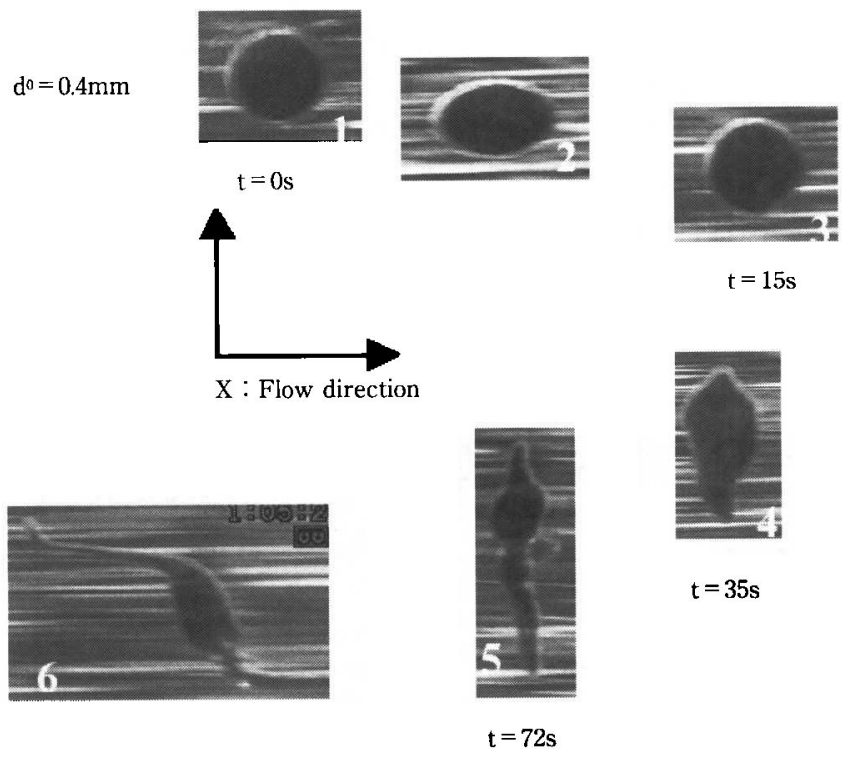

図 2 ニュートン流体中の Boger 流体液的の变形と分裂 (せん断速度 $26 \mathrm{~s}^{-1}$ )
Coupez $z^{4}$ らは時間一空間の $4 \mathrm{D}-\mathrm{FEM} に よ る$ 時間進行の 安定化と不連続ガラーキン法による移流項の安定化, さら には彼らの得意とするアダプティブメッシングを用いて非 定常の自由表面流れを追う手法を開発した。射出成形の 3 D 充填解析を実験結果と比較し，良い一致を示している. 特に自由表面をアダプティブメッシュで追う方法が非常に 優れるとの印象を受けた. ちなみに彼らは本手法の今後の ターゲットの 1 つとして二軸押出機の非定常解析を挙げて いる.

以上，押出成形分野を中心に学会報告を行ったが，前述 の通り本学会での押出成形は発表件数もさることながら， 応用分野も多岐にわたっており，またそれぞれの講演に対 して内容の濃い討論が交わされた. 次回成形加エシンポジ アでは押出成形に関する総合的なセッションが予定されて おり，このような押出成形に関する多様な分野での活発な 議論が行われることを期待したい.

最後に，交通の便はあまり良くないGuimarãesではあっ たが，中世の面影を残す町並みは素晴らしく，学会の合間 に旧市街を散策して，すっかりこの町が気に入ってしまっ たことを付け加えておく.

\section{発表者と発表題目}

1) Vergnes, B. : 'Residence Time Distribution in Corotating Twin Screw Extruders: Experiments and Modeling'

2) Bastian, M., Gabor, Th. and Reinheimer, P.: 'New Experimental Possibilities for the Investigation of the Melting of Polymer Blends'

3) Mighri, F. and Huneault, M. A.: 'Visualization of Dispersion in Polymer Blends'

4) Coupez, T., J. Bruchon, and Batkam, S.: 'SpaceTime Finite Element Method for 3D Process Modeling' 